\title{
architectural drawings
}

an expanding field

notes from the archive
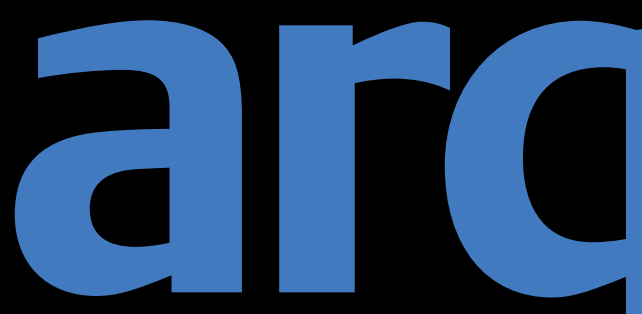

architectural research quarterly

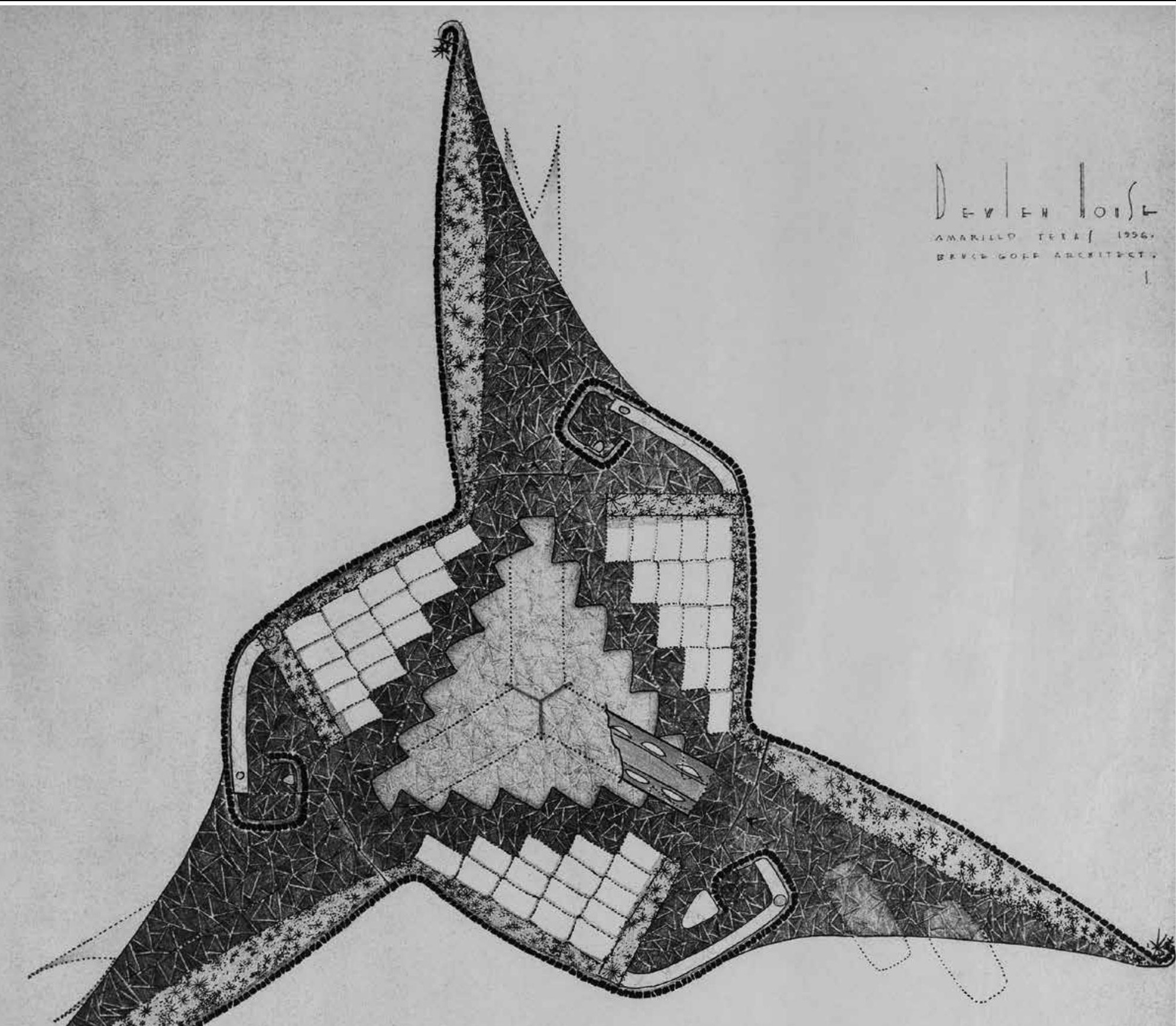

CAMBRIDGE UNIVERSITY PRESS 
Editor-in-Chief Adam Sharr

E. adam.sharr@ncl.ac.uk

Editor-at-Large Richard Weston

E. richard@richardwestonstudio.com

Editors Samuel Austin

E. samuel.austin@ncl.ac.uk

Martyn Dade-Robertson

E. martyn.dade-robertson@ncl.ac.uk

Graham Farmer

E. graham.farmer@ncl.ac.uk

Zeynep Kezer

E. zeynep.kezer@ncl.ac.uk

Katie Lloyd Thomas

E. katie.1loyd-thomas@ncl.ac.uk

Juliet Odgers

E. juliet.odgers@ncl.ac.uk

Stephen Parnell

E. stephen.parnell@ncl.ac.uk

Editor Edward Wainwright

Reviews + Insight $\quad$ E. edward.wainwright@ncl.ac.uk

Assistant Editor Ruth Lang

Reviews + Insight $\quad$ E. r.lang2@ncl.ac.uk

Editorial Assistant Ashley Mason

E. arq@ncl.ac.uk

Art Editor + Design Angela Ashton

E. design@angelaashton.co.uk

Editorial Board Simon Allford Allford Hall Monaghan Morris, UK Andrew Ballantyne Newcastle University, UK

Mark Burry The University of Melbourne, Australia

Carlos Eduardo Comas Universidade Federal do Rio Grande do Sul, Brazil

Richard Coyne The University of Edinburgh, UK

Peggy Deamer Yale University, UsA

Susannah Hagan University of Westminster, UK

Francine Houben Mecannoo, Holland

Susanne Hofmann Die Baupiloten, TU Berlin, Germany

Louisa Hutton Sauerbruch Hutton, Germany

Mari Hvattum The Oslo School of Architecture and Design, Norway

Timothy W. Hyde MIT, USA

Momoyo Kaijima Atelier Bow-Wow, Japan

Silke Kapp Universidade Federal de Minas Gerais, Brazil

Ulrika Karlsson Kтн, Sweden

David Leatherbarrow University of Pennsylvania, USA

Lesley Lokko University of Johannesburg, South Africa

Mary McLeod University of Columbia, USA

Steven A. Moore The University of Texas at Austin, USA

Michael Ostwald The University of Newcastle, Australia

Simo Paavilinen Aalto University, Finland

Jane Rendell Bartlett School of Architecture, UCL, UK

Daniel Rosbottom TU Delft, Holland

Andreas Rumpfhuber Expanded Design, Austria

Simon Sadler University of California, Davis, USA

Flora Samuel University of Reading, UK

Jonathan Sergison Sergison Bates Architects, UK

Despina Stratigakos University at Buffalo, USA

Koen Steemers University of Cambridge, UK

John Tuomey O'Donnell + Tuomey, Ireland

Sarah Wigglesworth Sarah Wigglesworth Architects, UK

jianfei Zhu The University of Melbourne, Australia

arq: Architectural Research Quarterly (issn 1359-1355) is published four times a year in March, June, September and December. Four parts form a volume. The subscription price which includes print and electronic access (but excluding vat) of volume 22 is $£_{328.00}$ (US \$551.00 in USA, Canada and Mexico) for institutions; $£_{5} 6.00$

(US $\$ 86.00$ in USA, Canada and Mexico) for individuals and $£_{4}$.0.00 (US $\$ 67.00$ in USA,

Canada and Mexico) for students, which includes print only, ordering direct from the publishers and certifying that the journal is for their personal use. Single parts are $€ 94.00$ net (US \$152.00 in USA, Canada and Mexico) plus postage. EU subscribers (outside the UK) who are not registered for vat should add vat at their country's rate. vat registered members should provide their vat registration number. Japanese prices for institutions (including ASP delivery) are available from Kinokuniya Company Ltd, P.O. Box 55, Chitose, Tokyo 156, Japan. Orders which must be accompanied by payment, may be sent to a bookseller, subscription agent or direct to the publisher: Cambridge University Press, Journals Fulfillment Department, UPH, Shaftesbury Road, Cambridge CB2 8BS, UK or in the USA, Canada and Mexico: Cambridge University Press, Journals Fulfillment Department, Liberty Plaza, Floor 20, New York, NY 10006, USA. Copies of the journal for subscribers in the USA, Canada and Mexico are sent by air to New York to arrive with minimum delay.

Copying

The journal is registered with the Copyright Clearance Center, 222 Rosewood Drive, Danvers, MA 01923, USA. Organizations in the USA who are also registered with C.C.C may therefore copy material (beyond the limits permitted by sections 107 and 108 of U.S. Copyright law) subject to payment to C.C.C. of the per-copy fee of \$16. This consent does not extend to multiple copying for promotional or commercial purposes. Code 1359-1355/2018/\$16.

ISI Tear Sheet Service, 3501 Market Street, Philadelphia, PA19104, USA, is authorized to supply single copies of separate articles for private use only.

Organizations authorized by the Copyrigh Licensing Agency may also copy material subject to the usual conditions.

For all other use, permission should be sought from Cambridge or from the American Branch of Cambridge University Press.

Information on arq: Architectural Research Quarterly and all other Cambridge journals can be accessed via http://www.journals.cambridge.org/

This journal issue has been printed on FSC-certified paper and cover board. FSC is an independent, non-governmental, not-for-profit organization established to promote the responsible management of the world's forests. Please see www.fsc.org for information.

OC Cambridge University Press 2018 
COVER

Plan of the Dewlen

House: APARTURE

Amarillo, Texas, 1956

designed by Bruce

Alonso Goff.

Seepp. 8-40.

\begin{tabular}{|c|c|c|}
\hline leader & 3 & Drawing matter \\
\hline report & 4 & Black Spaces Matter Dariel Cobb \\
\hline drawing matter & 8 & $\begin{array}{l}\text { Drawing matter: Plan Stan Allen, Niall Hobhouse and Helen Mallinson offer a } \\
\text { selection of plan drawings from the Drawing Matter archive - paired as visual rhymes } \\
\text { or striking contrasts - and reflect on the plan drawing as a paradoxical sort of object. }\end{array}$ \\
\hline
\end{tabular}

history $\quad 41 \quad$ Beyond instrumental use: a study of writing on architectural drawings in the late twentieth century Sonit Bafna and Hoyoung Kim show how the sudden theoretical interest in architectural drawing during the 1980 s, accompanying a new trend in presentation drawings, reveals interesting insights into architectural practice.

theory 55 Architecture's expanding field: AD magazine and the Post-Modernisation of architecture Stephen Parnell discusses AD's role in architecture's turn towards culture in the 1980 s and how Post-Modernism should be considered more a cultural turn for architecture than purely stylistically.

69 Frank Lloyd Wright's posthumous architecture Ashley Paine and Amy Clarke consider how the posthumous construction of Frank Lloyd Wright's unbuilt archive presents often unacknowledged and unexamined challenges to his recognised canon and to the discipline of architecture.

Translation in the architectural phenomenology of Christian Norberg-Schulz Anna Andersen examines an unpublished note from the Norberg-Schulz archive for the insights it gives into his notion of 'translation' and theory of genius loci.

review 91

Reviewed by Polly Gould

subscribe 